\title{
Breast cancer stem cell selectivity of synthetic nanomolar-active salinomycin analogs
}

Xiaoli Huang ${ }^{1}$, Björn Borgström² ${ }^{2}$ Sebastian Kempengren ${ }^{1}$, Lo Persson ${ }^{3}$, Cecilia Hegardt ${ }^{4}$, Daniel Strand ${ }^{2 *}$ and Stina Oredsson ${ }^{1 *}$

\begin{abstract}
Background: Cancer stem cells (CSCs) have been invoked in resistance, recurrence and metastasis of cancer. Consequently, curative cancer treatments may be contingent on CSC selective approaches. Of particular interest in this respect is the ionophore salinomycin, a natural product shown to be 100-fold more active against CSCs than clinically used paclitaxel. We have previously reported that synthetic salinomycin derivatives display increased activity against breast cancer cell lines. Herein we specifically investigate the CSC selectivity of the most active member in each class of C20-O-acylated analogs as well as a C1-methyl ester analog incapable of charge-neutral metal ion transport.

Methods: JIMT-1 breast cancer cells were treated with three C20-O-acylated analogs, the C1-methyl ester of salinomycin, and salinomycin. The effects of treatment on the CSC-related $\mathrm{CD} 44^{+} / \mathrm{CD} 24^{-}$and the aldehyde dehydrogenase positive $\left(\mathrm{ALDH}^{+}\right)$populations were determined using flow cytometry. The survival ability of CSCs after treatment was investigated with a colony formation assay under serum free conditions. The effect of the compounds on cell migration was evaluated using wound-healing and Boyden chamber assays. The expression of vimentin, related to mesenchymal traits and expression of E-cadherin and $\beta$-catenin, related to the epithelial traits, were investigated using immunofluorescence microscopy.

Results: Treatment with each of the three C20-acylated analogs efficiently decreased the putative CSC population as reflected by reduction of the $\mathrm{CD} 44^{+} / \mathrm{CD}_{24} 4^{-}$and $\mathrm{ALDH}^{+}$populations already at a $50 \mathrm{nM}$ concentration. In addition, colony forming efficiency and cell migration were reduced, and the expression of the epithelial markers E-cadherin and $\beta$-catenin at the cell surface were increased. In contrast, salinomycin used at the same concentration did not significantly influence the CSC population and the C1-methyl ester was inactive even at a $20 \mu \mathrm{M}$ concentration.

Conclusions: Synthetic structural analogs of salinomycin, previously shown to exhibit increased activity against cancer cells, also exhibited improved activity against CSCs across several assays even at nanomolar concentrations where salinomycin was found inactive. The methyl ester analog of salinomycin, incapable of charge-neutral metal ion transport, did not show activity in CSC assays, lending experimental support to ionophoric stress as the molecular initiating event for the CSC effects of salinomycin and related structures.
\end{abstract}

Keywords: Salinomycin, Salinomycin analogs, Breast cancer stem cells, Migration, Mesenchymal to epithelial transition

\footnotetext{
* Correspondence: daniel.strand@chem.lu.se; stina.oredsson@biol.lu.se

${ }^{2}$ Department of Chemistry, Center for Analysis and Synthesis, Lund

University, Lund, Sweden

'Department of Biology, Lund University, Lund, Sweden

Full list of author information is available at the end of the article
}

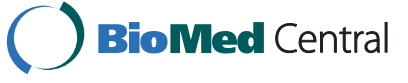

(c) 2016 Huang et al. Open Access This article is distributed under the terms of the Creative Commons Attribution 4.0 International License (http://creativecommons.org/licenses/by/4.0/), which permits unrestricted use, distribution, and reproduction in any medium, provided you give appropriate credit to the original author(s) and the source, provide a link to the Creative Commons license, and indicate if changes were made. The Creative Commons Public Domain Dedication waiver (http://creativecommons.org/publicdomain/zero/1.0/) applies to the data made available in this article, unless otherwise stated. 


\section{Background}

Breast cancer is the leading cause of cancer death among women worldwide. Often, this outcome is a consequence of recurrence following years of disease-free life after a completed initial treatment [1]. Recurrence has been linked to certain treatment resistant cancer cells, coined cancer stem cells (CSCs), which share many of the properties associated with regular stem cells including self-renewal and differentiation [2]. Several studies have shown enrichment of CSCs following conventional chemotherapeutic treatment, both in vivo and in cancer cell lines $[3,4]$. This has lead to the proposal that the chemotherapeutic drugs mainly target bulk cancer cells while sparing cells with CSC properties $[5,6]$. Curative treatments may therefore be contingent on therapies that target both CSCs and bulk cancer cells, presumably by a combination of conventional therapies and CSC selective drugs. Of particular interest in a breast cancer context is the natural product salinomycin. Salinomycin was identified in a screen for breast CSC inhibition [7] and has subsequently been shown to inhibit CSCs of many cancer types [8-10]. Salinomycin has been shown to inhibit cell migration and cell proliferation as well as inducing apoptosis and autophagy [11-15]. Proposed mechanisms include inhibition of Wnt [16-18] and Hedgehog signaling [19], inhibition of multidrug efflux systems [20, 21], induction of reactive oxygen species [22, 23], cleavage of polyADP-ribose polymerase [24, 25], and induction of DNA damage [26]. However, the actual molecular initiating event in the CSC or cancer cell adverse outcome pathways has not been clarified. As evidenced by the number of different mechanisms proposed, the actual initiating event may be obfuscated by the high treatment concentrations often used. It is well known that salinomycin is a potent ionophore with the capacity to transport alkali metal ions and it has been suggested that it acts in biological membranes by promoting potassium ion efflux $[27,28]$.

Despite the mechanistic uncertainty, salinomycin has been used in limited clinical trials showing positive responses [28, 29]. Towards increasing the clinical relevance of salinomycin, there is thus considerable interest in more active and selective structures acting through the same mechanism as well as developing an understanding of how such compounds selectively reduce CSC populations. We have previously demonstrated that selective chemical modification of salinomycin at the C20 hydroxyl group can be used to access significantly more active analog structures with $\mathrm{IC}_{50}$ values down to below one fifth of that of the native structure in two breast cancer cell lines [30]. In fact, these compounds represent the most active salinomycins known. In addition, chemical modifications at other positions of salinomycin as well as the anti proliferative effects of such derivatives have been described [30-35].

Herein, we show that the enhanced activity of the most active analog in each of the ester, carbamate and carbonate series of C20-O-acylated structures identified in our previous study (Fig. 1) also translates to superior selectivity against putative CSCs as compared to salinomycin itself. Treatment with each of the C20-acylated analogs efficiently reduced traits related to CSC activity in three different assays already at low nanomolar concentrations where salinomycin itself did not show activity. The unique potency of C20-O-acylated structures should be of interest in clinical settings where specific pharmacological activity at low concentrations is highly favorable. Of mechanistic significance, salinomycin C1-methyl ester (Fig. 1), a structure lacking the primary ion-binding motif of salinomycin, the carboxylic acid moiety, was also evaluated in parallel. Despite sharing the basic molecular framework of salinomycin, this structure, which is incapable of chargeneutral metal ion transport, did not show CSC selective properties. This finding is in line with disturbances in ion gradients as the main molecular initiating event and suggests that CSCs can, at least in part, be inhibited by such a mechanism.

\section{Methods}

In this study, the well-established commercially available human breast cancer cell line JIMT-1 (ACC589) was used and no ethical approval was required.

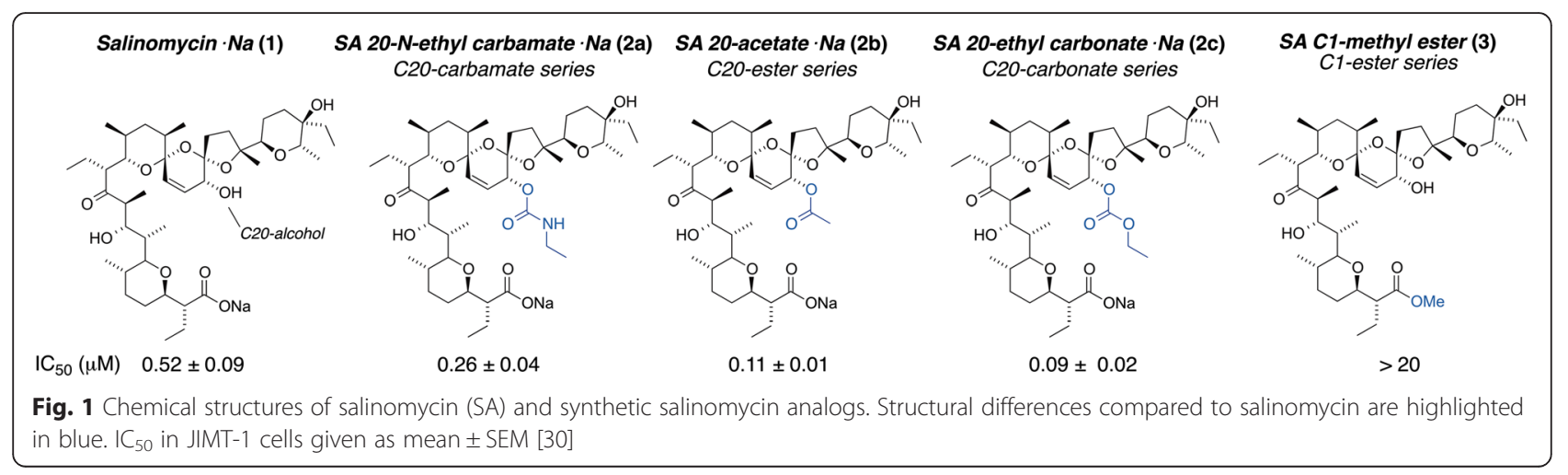




\section{Cell line and culturing conditions}

The human breast carcinoma cell line JIMT-1 (ACC589) was purchased from the German Collection of Microorganisms and Cell Cultures (DSMZ) and was routinely cultured in Dulbecco's modified Eagle's medium/Ham's F-12 nutrient mixture (1/1) supplemented with $10 \%$ fetal calf serum (FCS), nonessential amino acids (1 mM), insulin $(10 \mu \mathrm{g} / \mathrm{ml})$, penicillin $(100 \mathrm{U} / \mathrm{ml})$ and streptomycin $(100 \mu \mathrm{g} / \mathrm{ml})$. The JIMT-1 cell line was established from a pleural metastasis of a 62-year old patient with breast cancer who was clinically resistant to trastuzumab [36]. It is a well-characterized estrogen receptor negative and HER 2 amplified cell line belonging to the HER2 plus sub-type of breast cancer [36, 37]. The JIMT-1 cell line contains phenotypically different cell populations based on expression of CSC markers CD44, CD24 and ALDH [38]. This cell line has been used in several studies to investigate effects on the CSC subpopulation [39-42].

The JIMT-1 cell cultures were kept at $37{ }^{\circ} \mathrm{C}$ in a humidified incubator with $5 \% \mathrm{CO}_{2}$ in air. If not specified below, the cells were seeded at a density of 20,000 cells/ $\mathrm{cm}^{2}$ using $0.2-0.3 \mathrm{ml}$ of medium per $\mathrm{cm}^{2}$ in a tissue culture dish with appropriate size for the respective assays. Active compounds were added $24 \mathrm{~h}$ after seeding, and the cells were sampled for the various analyses after $72 \mathrm{~h}$ of treatment. Cell counting was performed in a hemocytometer.

\section{Compounds}

Technical grade salinomycin (12\%) was obtained from Chemtronica AB. This material was purified as described previously [30] and salinomycin was isolated and used as its sodium salt. Salinomycin analogs 2a-c and methyl ester 3 were synthesized according to [30]. Analogs 2a-c were used as the respective sodium salt. The compounds were diluted in $100 \%$ dimethyl sulfoxide (DMSO) to a $10 \mathrm{mM}$ stock solution which was kept at $4{ }^{\circ} \mathrm{C}$. The compounds were diluted in phosphate-buffered saline (PBS) to give working solutions at appropriate concentrations. The controls were supplemented with PBS containing DMSO at the same concentrations as in the working solutions of the compounds. The final DMSO concentration was $0.2 \%$ when using the $\mathrm{C} 20-\mathrm{O}$-acylated analogs at the $\mathrm{IC}_{50}$ concentration [30]. An $\mathrm{IC}_{50}$ was not obtained for the salinomycin C1-methyl ester [30] and it was used at a $20 \mu \mathrm{M}$ concentration in experiments comparing effects at $\mathrm{IC}_{50}$. The DMSO concentration was $0.0005 \%$ when using the compounds at a $50 \mathrm{nM}$ concentration.

\section{Cell cycle analysis by flow cytometry}

After $72 \mathrm{~h}$ of treatment, cells were harvested by trypsinization and fixed in ice-cold $70 \%$ ethanol for at least $1 \mathrm{~h}$ at $-20{ }^{\circ} \mathrm{C}$. The cells were then stained and analyzed as described previously [43]. The assay does not distinguish between $G_{0}$ and $G_{1}$ cells, thus, when $G_{1}$ is mentioned in the text and figures it denotes both populations. Since the method removes the cell membranes, cells in mitosis (M) are not included in the assay.

\section{Western blot}

After $72 \mathrm{~h}$ of treatment, cells were harvested using Accutase (Sigma) for $10 \mathrm{~min}$ at $37{ }^{\circ} \mathrm{C}$, then counted, pelleted and stored at $-80{ }^{\circ} \mathrm{C}$ until further use. The Western blot was performed as described previously [42].

\section{Cell surface markers identified by flow cytometry}

Cells were harvested using Accutase and identified based on their expression of the cell surface markers CD44 and CD24 using a BD Accuri C6 as described previously [35]. Antibodies used for flow cytometry (CD44-fluorescein isothiocyanate (FITC)-conjugated (clone G44-26), CD24-phycoerythrin (PE)-conjugated (clone ML5) and PE-conjugated or FITC-conjugated mouse IgG1 isotype controls (MOPC-21)) were purchased from BD Biosciences. Labeling with 7-aminoactinomycin D (7AAD) was initially used to gate only live cells, but this staining could be omitted since dead cells were typically not seen and usage of 7AAD should be minimized as this is a potent carcinogen. In addition, the cell harvesting procedure included a rinsing step that removed detached dead cells.

\section{ALDEFLUOR assay}

The ALDEFLUOR kit (Stem Cell Technologies) was used according to the manufacturer's protocol. The cells were harvested using Accutase and after cell counting, two test tubes containing 200,000 cells in assay buffer were prepared for each sample. One of the test tubes was used as negative control receiving the specific ALDH inhibitor diethylaminobenzaldehyde (DEAB). Then the ALDH substrate BODIPY-amino acetaldehyde was added to both tubes which were incubated for $45 \mathrm{~min}$ at $37^{\circ} \mathrm{C}$. After incubation, the cells were pelleted by centrifugation and the cells were resuspended in $500 \mu \mathrm{l}$ assay buffer before analysis in a BD Accuri C6 flow cytometer. DEAB-treated cells served as control to set the $\mathrm{ALDH}^{+}$region for each sample. The CFlow software was used to evaluate the data.

\section{Colony formation assay in soft agar}

The colony formation assay was performed as described previously [35].

\section{Wound-healing assay}

JIMT- 1 cells were seeded in 6-well plates $(125,000$ cells/ $\mathrm{cm}^{2}$ ) and allowed to attach for $24 \mathrm{~h}$ resulting in a confluent layer of cells. The medium was removed and three scratches (wound areas) were made in the cell layer with 
a sterile $200 \mu$ l pipette tip. After washing twice with PBS, medium without FCS containing $0.0005 \%$ DMSO (control) or the respective compound at a concentration of $50 \mathrm{nM}$ was added to the wells. The scratch area was photographed directly (time 0 ), as well as after 24,48 and $72 \mathrm{~h}$ of treatment in an inverted phase contrast microscope. The migration was estimated by measuring the scratch area at $0,24,48$ and $72 \mathrm{~h}$ of treatment with ImageJ $1.47 \mathrm{v}$ software. The scratch area at each time point was divided with the area at $0 \mathrm{~h}$ to obtain a measure of wound closure. The wound area was defined as $0 \%$ closed at $0 \mathrm{~h}$ for each sample.

\section{Boyden chamber cell migration assay}

JIMT-1 cells were detached with Accutase, the cell number determined by counting in a hemocytometer and the cells were then diluted in serum free medium to a concentration of 50,000 cells $/ 250 \mu \mathrm{l}$. The cell suspension was incubated for $30 \mathrm{~min}$ at $37{ }^{\circ} \mathrm{C}$ in a water bath to acclimatize the cells to the serum free medium. The cells in serum-free medium were then seeded (50,000 cells) in tissue culture inserts with membranes having $8.0 \mu \mathrm{m}$ pores (BD Falcon ${ }^{\mathrm{TM}}$ Cell Culture Inserts). The inserts were then placed into the wells of 24-well plates containing $500 \mu \mathrm{l}$ medium with $10 \%$ FCS. The compounds were added to both the inserts and to the wells to a concentration of $50 \mathrm{nM}$ while control received $0.0005 \%$ DMSO. The 24-well plates were incubated in the $\mathrm{CO}_{2}$ incubator for $24 \mathrm{~h}$. The cells that had migrated through the pores of the membrane were fixed and stained with cell stain (Millipore, part No. 90144) for $20 \mathrm{~min}$. The trans wells were rinsed in Millipore water and nonmigrated cells removed with cotton swabs. The membranes were then left to air-dry. Ten photos were taken of each membrane in an inverted phase contrast microscope. Migrated cells were counted and the mean of migrated cells for each sample was compared to control.

\section{Immunofluorescence microscopy}

JIMT-1 cells were plated on poly-L-lysine-coated glass slides and treated with $50 \mathrm{nM}$ compound or $0.0005 \%$ DMSO as control for $72 \mathrm{~h}$. After fixation in $3.7 \%$ paraformaldehyde (in PBS) for $15 \mathrm{~min}$ and subsequent washing in PBS, the cells were permeabilized with PBS containing $1 \%$ Tween 20 and $1 \%$ bovine serum albumin in a single step. The cells were incubated with primary antibody against vimentin (1:100), $\beta$-catenin (1:500) or E-cadherin (1:100) for $1 \mathrm{~h}$ at room temperature. Antibodies against vimentin (ab8978) and E-cadherin (ab1416) were purchased from Abcam. Antibody against $\beta$-catenin (610154) was purchased from BD Biosciences. After washing, the cells were incubated for $1 \mathrm{~h}$ with the Alexa Fluor 488 goat anti mouse (1:300) antibody (Invitrogen). Slides were counter-stained with bisbenzimide (Hoechst 33258) (1 $\mu \mathrm{g} /$ $\mathrm{ml}$ in PBS) for 2 min and finally washed with PBS before mounting. The cells were viewed in an Olympus/Nikon epifluorescence microscope (Olympus Optical Co. Ltd.) and photos were taken with a digital camera (Nikon Imaging Japan Inc.). Each slide was photographed at randomly chosen areas (at least 8 areas).

\section{Statistical analysis}

The software program GraphPad Prism 6 was used for statistical analysis. A one-way ANOVA test, using the no matching or paring option, was used to detect difference between control and treated samples. To compare the mean of each column with the mean of a control, the Dunnet multiple comparisons test was applied using a $95 \%$ confidence interval.

\section{Results}

C20-O-acylated analogs are more efficient than salinomycin against breast CSCs at a $50 \mathrm{nM}$ concentration

Breast CSCs have been identified based on a high expression of CD44 paired with absent/low expression of CD24 on the cell surface [44]. We have previously shown that salinomycin (1) gave the highest selective activity against $\mathrm{CD} 44^{+} / \mathrm{CD} 24^{-}$cells at $\sim \mathrm{IC}_{25}$ in the breast cancer cell line JIMT-1 [35]. Thus, we decided to investigate the CSC activity of the analogs $\mathbf{2 a - c}$ in this cell line using a $50 \mathrm{nM}$ concentration, which corresponds to the approximate $\mathrm{IC}_{25}$ values for these structures. At this concentration, we found that treatment with each of the C20 analogs efficiently reduced the $\mathrm{CD} 44^{+} / \mathrm{CD} 24^{-}$subpopulation while treatment with salinomycin or the salinomycin C1-methyl ester $\mathbf{3}$ had no observable effect (Fig. 2a and Additional file 1: Figure S1). We have previously shown that treatment with varying concentrations of salinomycin gives a U-shaped dose response curve with the maximum reduction of the $\mathrm{CD} 44^{+} / \mathrm{CD} 24^{-}$ around $\mathrm{IC}_{25}$ [35], and this was also found to be the case for the more active analogs as exemplified by carbamate 2a (Additional file 2: Figure S2). To account for this effect in JIMT-1 cells following treatment with salinomycin or either of the two related structures SY-1 and 18,19-dihydro SY-1, we have previously discussed the relation between a decrease in the total cell number and the decrease in the population of $\mathrm{CD} 44^{+} / \mathrm{CD} 24^{-}$cells at various concentrations [35]. At concentrations up to $\mathrm{IC}_{25}$, the reduction in cell number only originated from a selective reduction of $\mathrm{CD} 44^{+} / \mathrm{CD} 24^{-}$cells but at concentrations above $\mathrm{IC}_{25}$, all populations were affected and at higher concentrations there was little or no reduction in the $\mathrm{CD} 44^{+} / \mathrm{CD} 24^{-}$population resulting in a U-shape dose response curve [35].

The most common trait of CSCs of different tumor origins appears to be expression of aldehyde dehydrogenase (ALDH) [45]. Treatment with $50 \mathrm{nM}$ of C20 analogs 


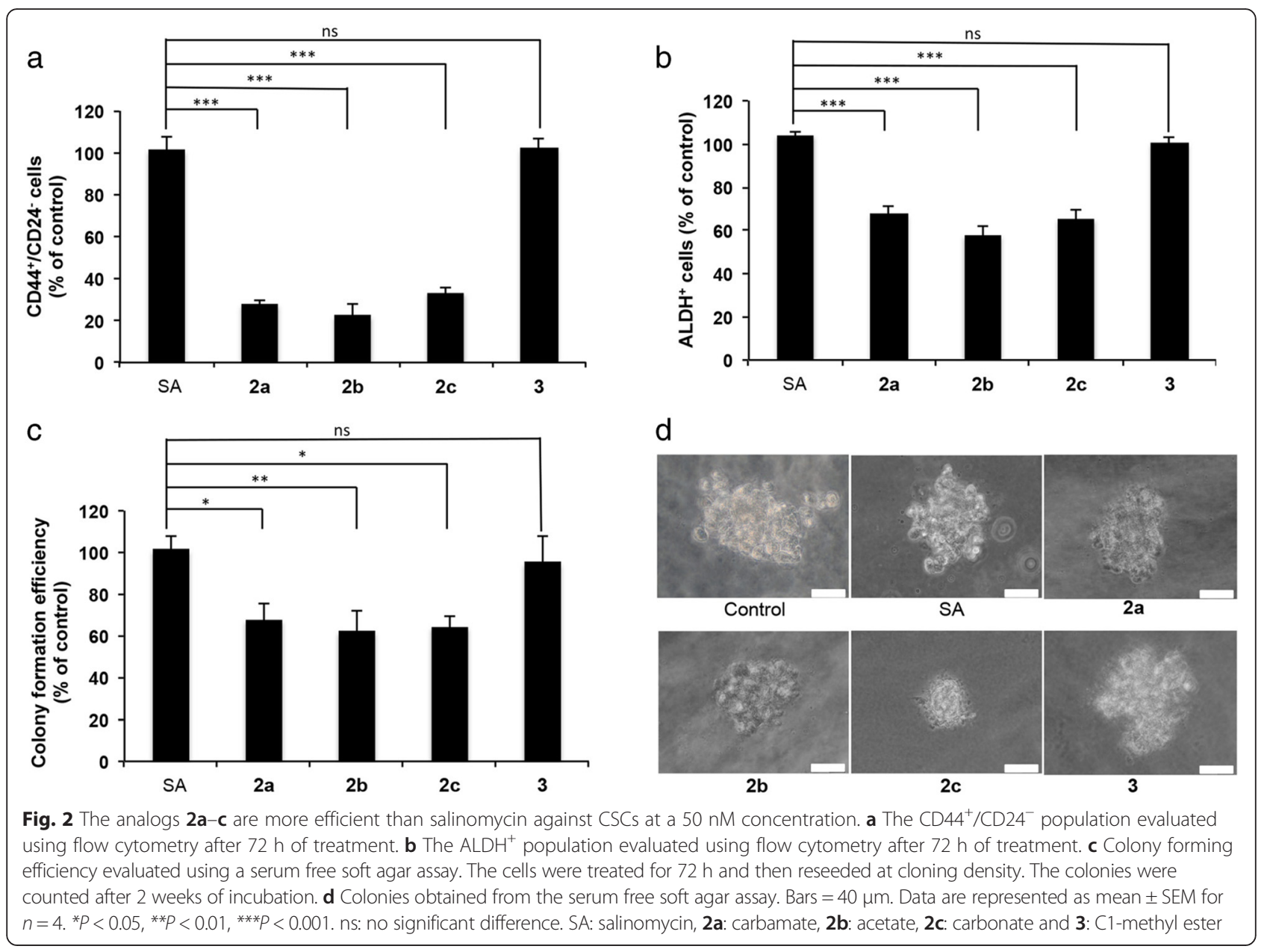

efficiently reduced the $\mathrm{ALDH}^{+}$population while treatment with salinomycin or the salinomycin C1-methyl ester had no observable effect (Fig. $2 \mathrm{~b}$ and Additional file 3: Figure S3). In contrast to the U-shaped dose response curve for $\mathrm{CD} 44^{+} / \mathrm{CD} 24^{-}$, varying the concentrations of salinomycin gave a dose dependent reduction in $\mathrm{ALDH}^{+}$cells (Additional file 4: Figure S4).

Colony forming efficiency in serum free soft agar is a functional assay which has been used to investigate survival potential of cells with stem cell properties in cancer cell lines [46]. We found that treatment with analogs at a $50 \mathrm{nM}$ concentration reduced the colony forming efficiency and colony size of JIMT-1 cells while treatment with salinomycin or the C1-methyl ester again had no observable effect at the same concentration (Fig. 2c and d).

\section{Treatment with C20 analogs increase the expression of} epithelial markers and decrease the expression of vimentin CSCs have been shown to exhibit properties that arise in the epithelial to mesenchymal transition (EMT) process and these properties contribute to the metastasis of cancer
[47-49]. Compounds that reduce the mesenchymal properties of CSCs should be of interest as a strategy for preventing metastasis. Some important traits of EMT are the loss of E-cadherin and $\beta$-catenin on the cell surface. $\beta$ Catenin is localized at cell-cell junctions and its association with E-cadherin leads to a stable epithelial structure. A loss of $\beta$-catenin from the cell membrane borders is seen in migratory mesenchymal cells $[50,51]$. An additional marker for cell mobility is an increased expression of the mesenchymal cytoskeletal protein vimentin.

Treatment with C20 analogs for $72 \mathrm{~h}$ increased the Ecadherin and $\beta$-catenin expression levels at the cell membrane while treatment with salinomycin and the C1-methyl ester did not give a noticeable effect on these protein levels (Fig. 3a and b). The expression of vimentin was decreased both by treatment with the C20 analogs and by salinomycin (Fig. 3c).

Taken together, the results show that the C20 analogs were more efficient at a $50 \mathrm{nM}$ concentration than salinomycin in increasing the expression of the epithelial markers at the cell surface. All compounds tested except the C1-methyl ester also decreased the 
a
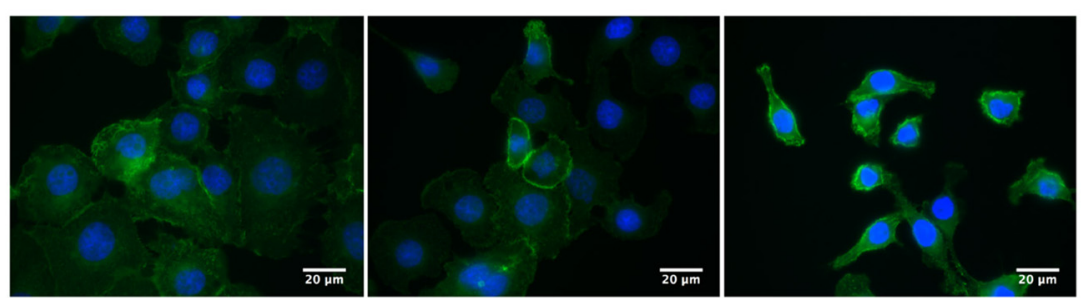

Control

SA

$2 a$
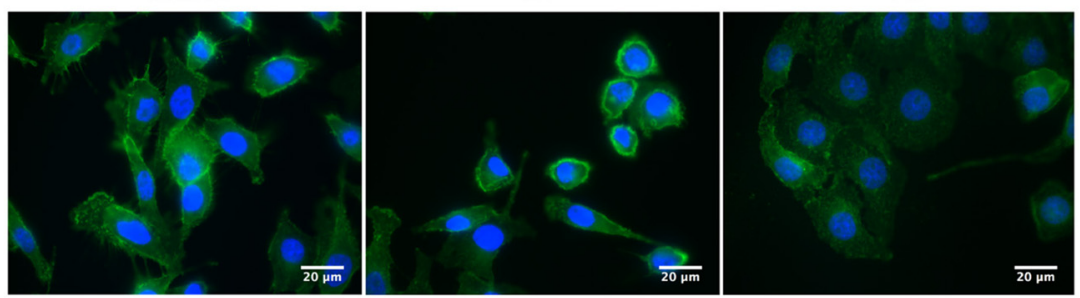

m

2b

2c

3

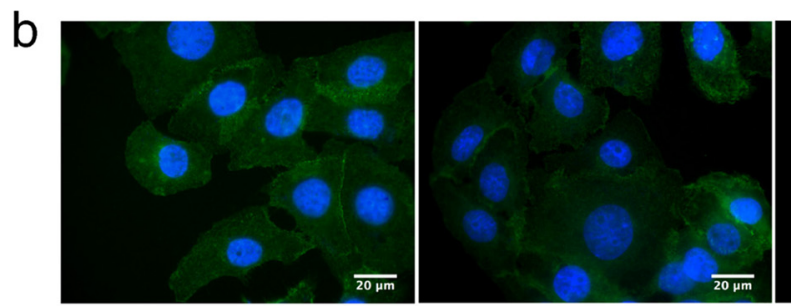

Control

SA

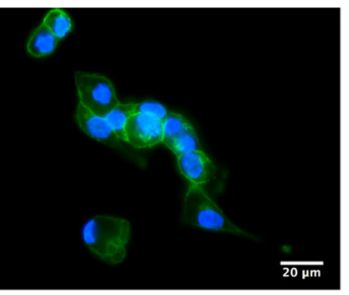

$2 a$

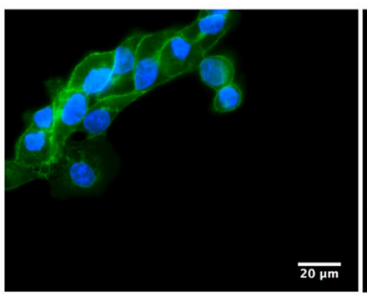

2b

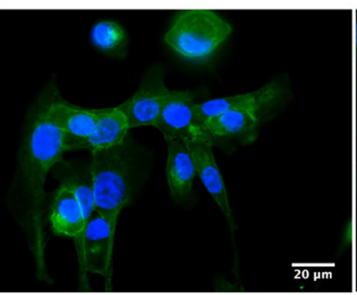

2c

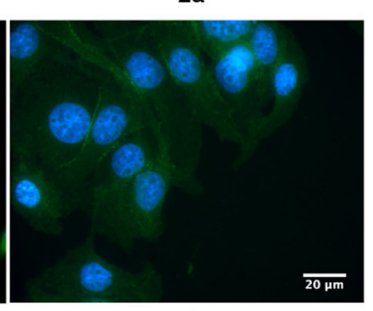

.

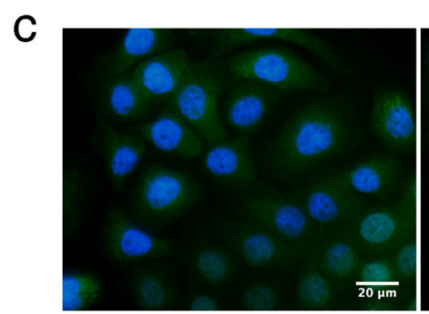

Control

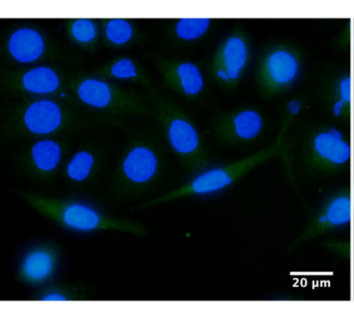

SA

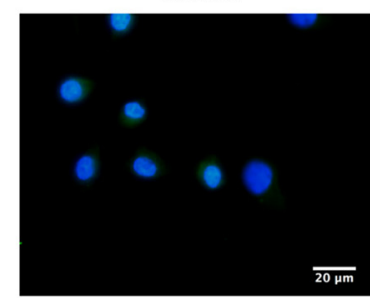

$2 b$

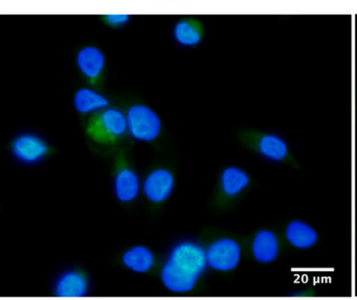

2c

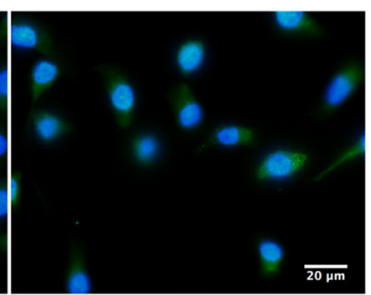

$2 \mathbf{a}$

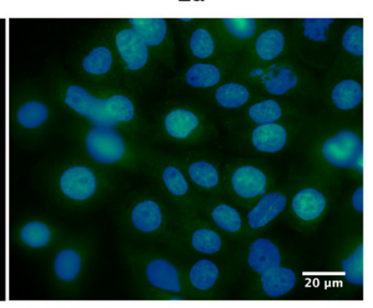

令

Fig. 3 Treatment with the analogs $\mathbf{2 a - c}$ induce expression of E-cadherin and $\beta$-catenin at the cell surface. The cells were treated with a $50 \mathrm{nM}$ concentration of the compounds for $72 \mathrm{~h}$. a-c E-cadherin, $\beta$-catenin and vimentin, respectively, detected with immunofluorescence microscopy after appropriate labeling with specific primary antibodies followed by secondary Alexa Fluor 488-conjugated antibodies (green). Nuclei were stained with bisbenzimide (blue). Bars $=20 \mu \mathrm{m}$. SA: salinomycin, 2a: carbamate, $\mathbf{2 b}$ : acetate, 2c: carbonate and 3: C1-methyl ester 
expression of the mesenchymal marker vimentin at this concentration.

\section{Treatment with C20-O-acylated analogs reduce cell migration}

A decreased expression of vimentin and increased expression of E-cadherin and $\beta$-catenin at the cell surface should lead to a cellular functional effect manifested in decreased migration. We thus investigated the effect of both the C20 analogs and salinomycin on cell migration using a $50 \mathrm{nM}$ concentration in wound-healing and Boyden chamber assays. Both assays showed that the acylated analogs as well as salinomycin reduced cell migration (Fig. 4). However, each of the acylated analogs was more efficient in inhibiting wound closure and cell migration than salinomycin at this concentration. The C1-methyl ester had no effect on migration compared to control.

Salinomycin and the C20 analogs exert CSC and cell cycle effects through the same mechanism of action

Compounds that exert activity through the same molecular mechanism should give similar effects upon treatment at $\mathrm{IC}_{50}$. When treating cells with each of the analogs and salinomycin at the respective $\mathrm{IC}_{50}$ (Fig. 1), all compounds except the C1-methyl ester (used at a $20 \mu \mathrm{M}$ concentration) reduced the $\mathrm{CD} 44^{+} / \mathrm{CD} 24^{-}$population to a similar extent. Moreover, treatment at $\mathrm{IC}_{50}$ also decreased the $\mathrm{ALDH}^{+}$cell population to around $50 \%$ of control while the C1-methyl ester at a $20 \mu \mathrm{M}$ concentration was inactive in this assay (Fig. 5a and b, Additional files 5 and 6: Figure S5 and S6). The same trend translated also to colony formation, although the C1-methyl ester at $20 \mu \mathrm{M}$ gave a slight decrease in colony forming efficiency (Fig. $5 \mathrm{c}$ and d). The C1-methyl ester is a xenobiotic and is used at a high concentration compared to the other compounds and thus some toxicity is not surprising. When compared to control, treatment with all compounds including the $\mathrm{C} 1$-methyl ester resulted in a significant decrease in the number of colonies formed $(p<0.0001$ for SA, 2a and $2 \mathbf{b} ; p=0.0002$ for 2c; $p=0.007$ for 3 ).

We also investigated the effects on cell cycle phase distribution and induction of cell death. When the cells were treated at the $\mathrm{IC}_{50}$ of salinomycin or the $\mathrm{C} 20$ analogs, the $\mathrm{G}_{1}$ phase increased and the $\mathrm{S}$ phase decreased (Fig. 5e). In contrast, cultures treated with the C1-methyl ester showed the same cell cycle phase distribution as control (Fig. 5e). None of the compounds induced cell death as evidenced

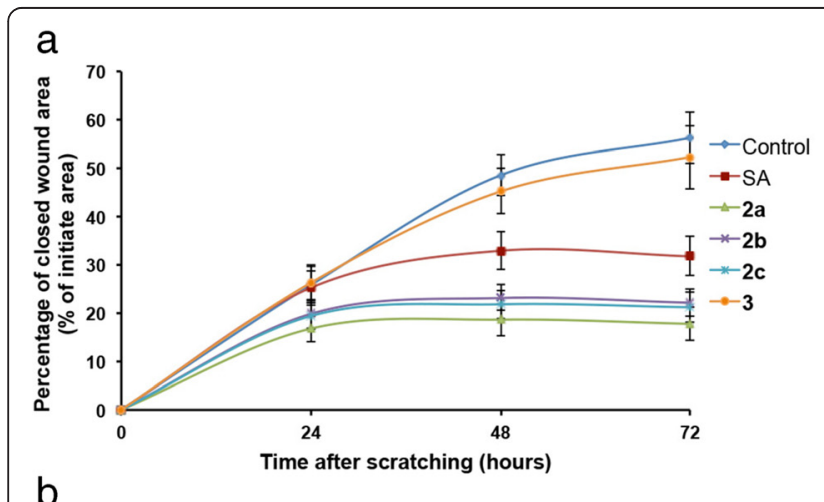

C

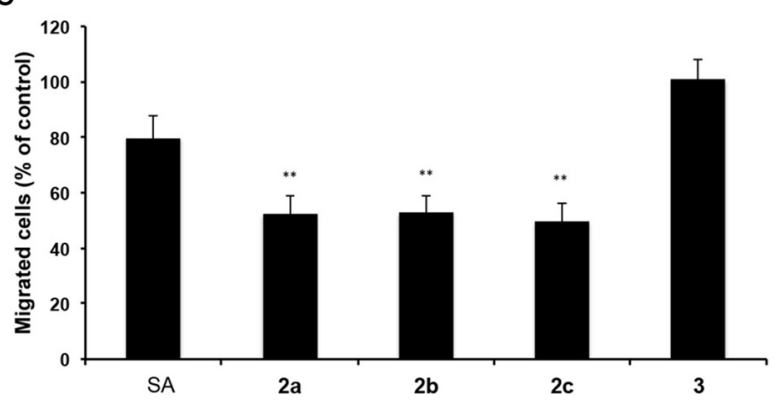

b

d

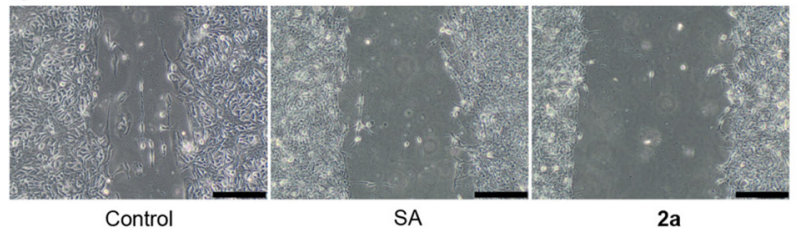

Control

$2 a$
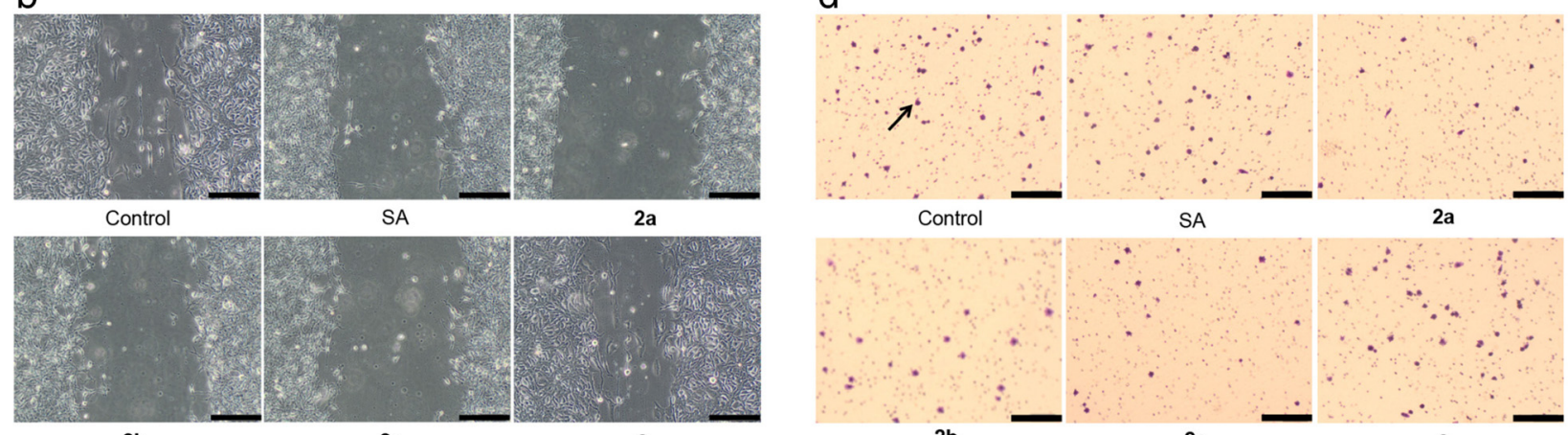

2b

2c

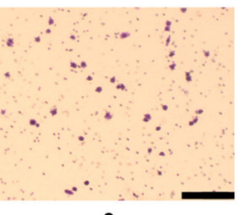

3

Fig. 4 Cell migration after treatment with a $50 \mathrm{nM}$ concentration of salinomycin or salinomycin analogs $\mathbf{2 a - c}$. a Quantification of wound healing. b Representative images of wound healing at $72 \mathrm{~h}$ after scratching. c Quantification of migrated cells in a Boyden chamber cell migration assay after $24 \mathrm{~h}$ of treatment. d Representative images of migrated cells. JIMT-1 cells were plated in trans wells with membranes containing 8.0 Hm pores in medium containing the indicated compound. After $24 \mathrm{~h}$ of treatment, cells that had migrated to the bottom of the trans well were stained and photographed. The arrow points to a migrated cell. The small dots are the pores. Data are represented as mean \pm SEM for $n=5$. Bars in $\mathbf{( b )}$ and $(\mathbf{d})=200 \mu \mathrm{m}$. SA: salinomycin, $\mathbf{2 a}$ : carbamate, $\mathbf{2 b}$ : acetate, $\mathbf{2 c}$ : carbonate and $\mathbf{3}$ : C1-methyl ester. ${ }^{*} \mathrm{P}<0.01$ compared to control 


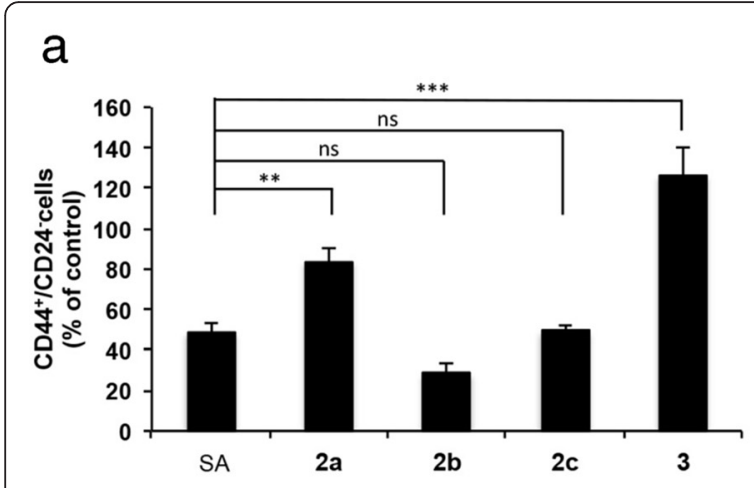

C
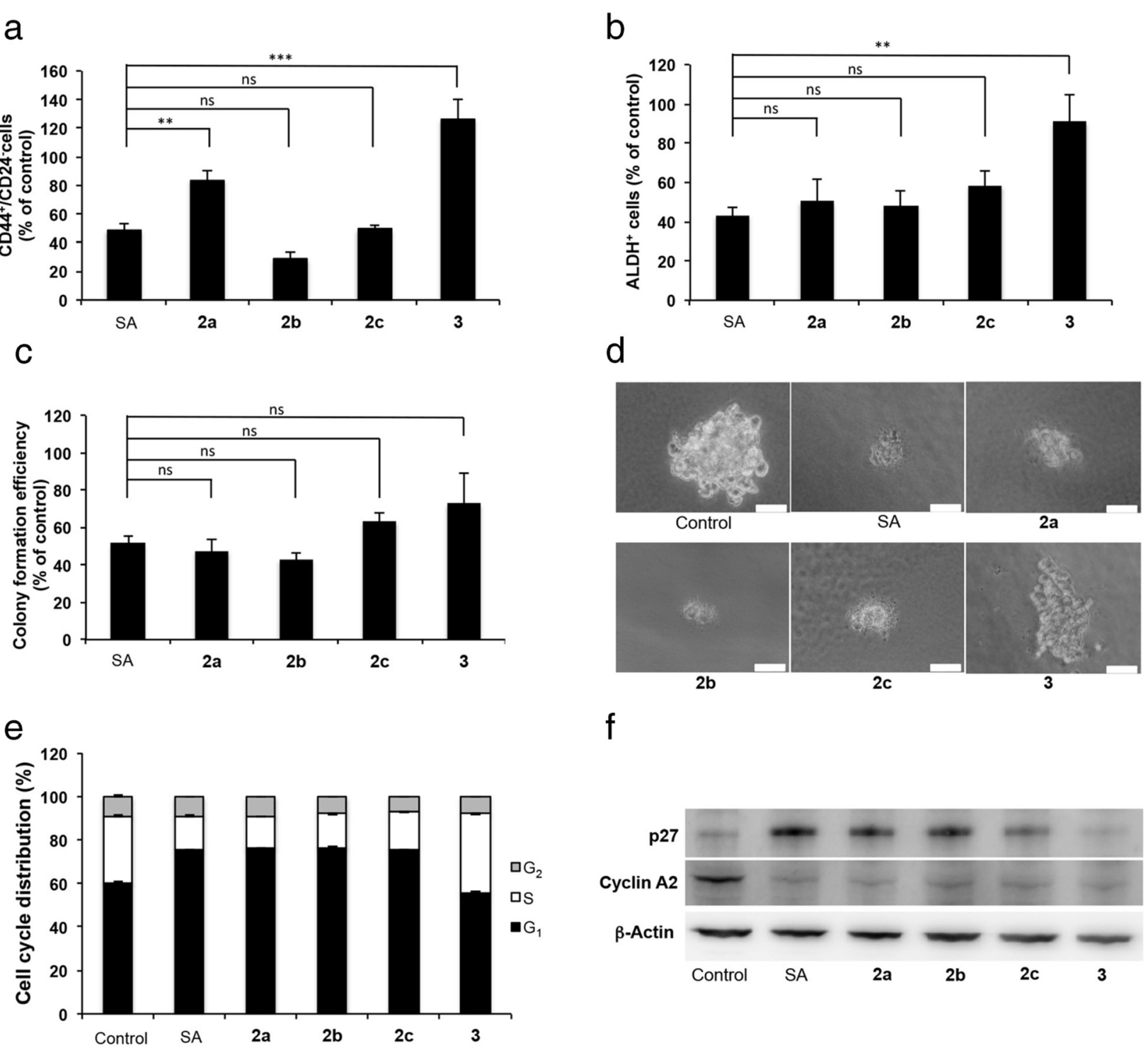

f
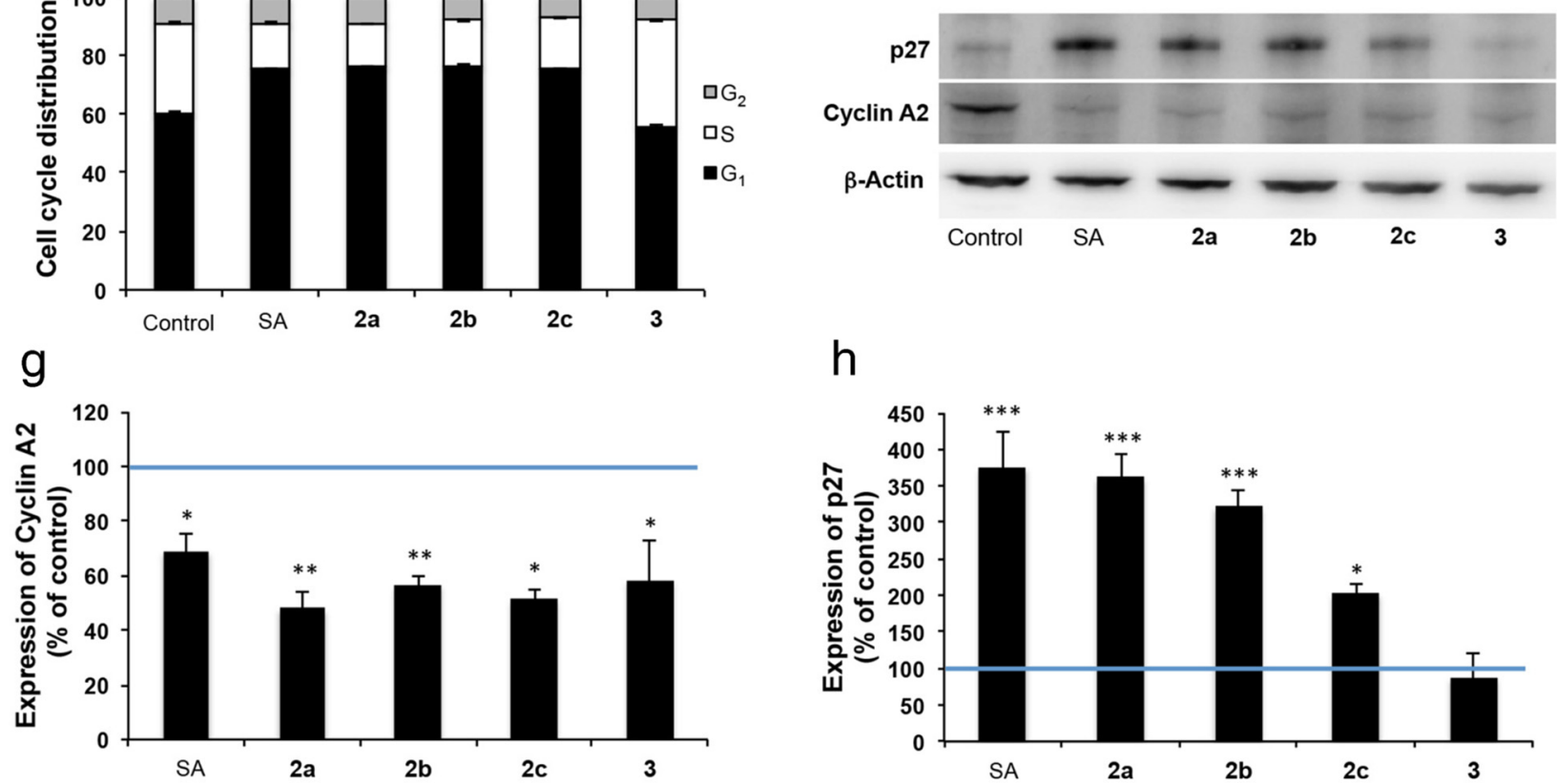

Fig. $\mathbf{5}$ Treatment with $I C_{50}$ of salinomycin and the analogs $\mathbf{2 a - c}$ result in similar effects on CSCs and cell proliferation. a The CD $44^{+} / \mathrm{CD} 24^{-}$population evaluated by flow cytometry after $72 \mathrm{~h}$ of treatment. $\mathbf{b}$ The $\mathrm{ALDH}^{+}$population evaluated by flow cytometry after $72 \mathrm{~h}$ of treatment. $\mathbf{c}$ Colony forming efficiency evaluated using a serum free soft agar assay. The cells were treated for $72 \mathrm{~h}$ and then reseeded at cloning density. The colonies were counted after 2 weeks of incubation. $\mathbf{d}$ Colonies obtained from the serum free soft agar assay. Bars $=40 \mu \mathrm{m}$. e Cell cycle phase distribution evaluated by flow cytometry. f Representative Western blots used for densitometric scanning. $\mathbf{g}-\mathbf{h}$ Expression of cyclin A2 and p27, respectively. Data are represented as mean \pm SEM for $n \geq 3$. The columns in (a-d) show mean \pm SEM for $n=4$. ${ }^{*} P<0.05,{ }^{*} P<0.01,{ }^{* *} P<0.001$. ns: no significant difference. SA: salinomycin, 2a: carbamate, $\mathbf{2}$ b: acetate, $\mathbf{2 c}$ : carbonate and $\mathbf{3}$ : C1-methyl ester 
by the absence of a sub- $\mathrm{G}_{1}$ signal in the DNA histogram (not shown). To gain insight into the molecular cause of the increase in the $G_{1}$ phase, proteins that have major roles in cell cycle progression through the $G_{1}$ and $S$ phases were investigated by Western blot analysis. The levels of cyclins D1 and E1, important for $G_{1}$ progression and $G_{1} / S$ transition, respectively, did not change compared to control after treatment with any of the compounds (not shown). However, the level of cyclin A2, important for $S$ phase progression, was significantly reduced by all compounds (Fig. $5 \mathrm{f}$ and g). The decrease in cyclin A2 is thus a reflection of a decreased $S$ phase. The $G_{1}$ accumulation in cells treated with $\mathrm{IC}_{50}$ of salinomycin or the $\mathrm{C} 20$ acylated analogs can be attributed to the significantly increased expression of the CDK/cyclin inhibitor p27 (Fig. $5 \mathrm{f}$ and h). The p27 level was not affected in cells treated with the C1-methyl ester. Expression of the CDK/cyclin inhibitor p21 was not affected by treatment with any of the compounds (not shown).

The cell cycle investigation shows that treatment with a $50 \mathrm{nM}$ concentration of the compounds resulted in a slight increase in the $\mathrm{G}_{1}$ phase of $\mathbf{2 c}$-treated cells compared to control while treatment with the other compounds resulted in a similar cell cycle phase distribution as control (Additional file 7: Figure S7). The level of cyclin A2 was the same in all treatment groups while p27 was increased in cells treated with $\mathbf{2 b}$ and $2 \mathbf{c}$ but substantially less compared to treatment with $\mathrm{IC}_{50}$ concentrations (compare Fig. 5 with Additional file 7: Figure S7). Analysis of the sub-G1 peak of DNA histograms did not show any sub-G1 peak as evidence of cell death in any of the treatment groups at a $50 \mathrm{nM}$ concentration (not shown).

\section{Discussion}

Using several independent CSC assays, a series of synthetic C20-O-acylated analogs of salinomycin reduced the putative CSC population in the JIMT-1 breast cancer cell line already at a $50 \mathrm{nM}$ concentration where salinomycin itself does not show activity. The synthetic analogs are thus significantly more active against CSCs than the native structure. The mechanism of action appears to be the same for all these compounds as several independent assays show that salinomycin and the $\mathrm{C} 20$ analogs give similar responses at the respective $\mathrm{IC}_{50}$.

Although salinomycin has been investigated extensively in a CSC context in recent years, the exact mechanism of action of this compound is not well understood. To this end, it is important that the C1methyl ester analog of salinomycin, a compound that retains the molecular structure of salinomycin, but displays an over three orders of magnitude reduced ionbinding ability [31] and is essentially incapable of charge-neutral ion transport, does not influence CSC-related properties even when used at higher concentrations. This gives experimental credence to the molecular initiating event for salinomycin and its C20 analogs as being related to disturbed membrane dependent ion gradients. These changes presumably then influence various signal transduction pathways and cell functions, which subsequently result in a decrease in the number of CSCs as well the mesenchymal traits of the cell population. Our data thus emphasize a significant role of the antiporter capacity of salinomycin and its more active $\mathrm{C} 20$ analogs rather than interaction with a specific cellular target. This notion is further corroborated by the prior observations that the related ionophores monensin and nigericin have similar effects as salinomycin $[7,52]$. The nature of the properties required for the high activity against CSCs of such structures however remains an open question. In particular, a potential connection between the CSC response and the alkali ion binding selectivity and transport efficiency is of interest in this context.

In addition to self-renewal and differentiation, CSCs have been shown to possess increased metastatic capacity, which is related to the process of EMT [53]. Salinomycin treatment has previously been shown to inhibit the ability of several cancer cell lines including prostate, colorectal and human bone marrow-derived mesenchymal stem cells to migrate when used at concentrations ranging from $50 \mathrm{nM}$ to $10 \mu \mathrm{M}[9,11,14,22,54,55]$. Our results show that the $\mathrm{C} 20$ analogs inhibited cell migration even more efficiently than salinomycin at a 50 $\mathrm{nM}$ concentration. Additionally, the expression of the epithelial markers E-cadherin and $\beta$-catenin at the cell surface was increased and the expression of the mesenchymal marker vimentin was decreased after treatment with the $\mathrm{C} 20$ analogs 2a-c. In contrast, treatment with $50 \mathrm{nM}$ salinomycin did not affect the expression of Ecadherin and $\beta$-catenin at the cell surface. The vimentin levels decreased after salinomycin treatment, which may explain the decreased rate of migration shown in the wound-healing and Boyden chamber assays although this effect was less pronounced than for the C20 analogs. Our data thus show that treatment with a $50 \mathrm{nM}$ concentration of the analogs $2 \mathbf{a}-\mathbf{c}$ increased the number of cells with epithelial phenotype while cells with mesenchymal phenotype decreased. In principle, the origin of this effect may be an induction of mesenchymal to epithelial transition (MET) i.e. a change in phenotype, but the same outcome would be achieved if there were selective death or growth inhibition of mesenchymal cells. An investigation of the sub- $G_{1}$ region in the cell cycle phase distribution of DNA histograms did not show induction of cell death upon treatment with a $50 \mathrm{nM}$ concentration of the analogs. As cell proliferation is slightly inhibited at $\mathrm{IC}_{25}$, the results can be interpreted as originating from inhibition of proliferation of mesenchymal 
cells and induction of MET in these cells. Similar results have been obtained when treating JIMT-1 cells with the anticancer polyamine analog PG11047 [42].

More active salinomycin analogs are of interest in light of the recent case reports where salinomycin treatment resulted in partial tumor and metastasis regression of breast cancer [28, 29]. Our results show that the synthetic $\mathrm{C} 20$ analogs exhibited improved activity against breast CSCs compared to salinomycin using several well-accepted traits of CSCs. These compounds moreover efficiently induced MET resulting in a decreased capacity of cell migration, a property closely related with metastasis of cancer. Importantly, these effects were seen for the synthetic C20 analogs already at low nanomolar concentrations where salinomycin itself was inactive. In particular, acetate $\mathbf{2} \mathbf{b}$ and the hydrolytically more stable ethyl carbonate 2c are attractive for further investigations as these compounds display similar enhanced activities in both MTT and CSC assays and can moreover be readily synthesized in high yields from abundantly available salinomycin [30].

\section{Conclusions}

We have previously shown that salinomycin derivatives, readily available in just a few synthetic steps, are significantly more active than salinomycin against breast cancer cells. Herein we show that these improvements in activity also translate to an enhanced selectivity against CSCs already at low nanomolar concentrations where salinomycin itself is inactive as shown by complementary markerbased and functional cell assays. Additionally, we show that traits associated with mesenchymal cells including cell migration and vimentin expression are efficiently reduced by the analog structures at low concentrations, while epithelial traits such as E-cadherin and $\beta$-catenin expression at the cell surface are increased reflecting a mesenchymal to epithelial transition. The similar responses across the assays when treating cells at the respective $\mathrm{IC}_{50}$ strengthens that salinomycin and its C20-acylated analogs, although varying in potency, exert their influence on the CSC population through a shared mechanism. While a number of downstream effects have been invoked in explaining the activity of salinomycin against CSCs, the molecular initiating event has remained unclear. Using the synthetic structural analogs as mechanistic probes, we lend experimental credence to ionophoric stress as the origin of the observed inhibition of CSCs. We anticipate that structural analogs of salinomycin that elicit similar cellular responses compared to the native structure but at significantly lower concentrations will be of immediate value both towards clinical relevance and for further mechanistic and biological investigations.

\section{Additional files}

Additional file 1: Figure S1. Representative cytograms of cell surface markers CD44 and CD24 obtained using flow cytometry. JIMT-1 cells were treated with $50 \mathrm{nM}$ salinomycin or salinomycin analogs for $72 \mathrm{~h}$. SA: salinomycin, 2a: carbamate, 2b: acetate, 2c: carbonate and 3: C1-methyl ester. (DOCX $1340 \mathrm{~kb}$ )

Additional file 2: Figure S2. U-shaped dose response curve found for the CD44 ${ }^{+} / \mathrm{CD}_{2} 4^{-}$population in N-ethyl carbamate 2a-treated JIMT-1 cells. JIMT-1 cells were treated with $2 \mathrm{a}$ for $72 \mathrm{~h}$ at the indicated concentrations. The effect on the CD44 ${ }^{+} / \mathrm{CD} 24^{-}$population was determined using flow cytometry. Data are represented as mean \pm SEM for $n=4$. (DOCX $41 \mathrm{~kb}$ )

Additional file 3: Figure S3. Representative cytograms of ALDH assay obtained using flow cytometry. JIMT-1 cells were treated with $50 \mathrm{nM}$ salinomycin or salinomycin analogs for $72 \mathrm{~h}$. SA: salinomycin, 2a: carbamate, 2b: acetate, 2c: carbonate and 3: C1-methyl ester. (DOCX 1678 kb)

Additional file 4: Figure S4. Salinomycin treatment decreases the proportion of $\mathrm{ALDH}^{+}$in a dose dependent manner. JIMT-1 cells were treated with salinomycin for $72 \mathrm{~h}$ at the indicated concentrations. The effect on the $\mathrm{ALDH}^{+}$population was determined using flow cytometry. Data are represented as mean \pm SEM for $n=3$. (DOCX $38 \mathrm{~kb}$ )

Additional file 5: Figure S5. Representative cytograms of cell surface markers CD44 and CD24 obtained using flow cytometry. JIMT-1 cells were treated with salinomycin or salinomycin analogs at $I C_{50}$ for $72 \mathrm{~h}$. SA: salinomycin, 2a: carbamate, 2b: acetate, 2c: carbonate and 3: C1-methyl ester. (DOCX $1331 \mathrm{~kb}$ )

Additional file 6: Figure S6. Representative cytograms of ALDH assay obtained using flow cytometry. JIMT-1 cells were treated with salinomycin or salinomycin analogs at $\mathrm{IC}_{50}$ for $72 \mathrm{~h}$. SA: salinomycin, 2a: carbamate, 2b: acetate, 2c: carbonate and 3: C1-methyl ester. (DOCX 1597 kb)

Additional file 7: Figure S7. Cell cycle effects of treating with $50 \mathrm{nM}$ salinomycin or the analogs $2 \mathrm{a}-\mathrm{c}$ for $72 \mathrm{~h}$. (a) Cell cycle phase distribution evaluated using flow cytometry. (b) Representative Western blots used for densitometric scanning to obtain the data in (c) and (d). (c-d) Expression of cyclin A2 and p27, respectively. The columns in (c) and (d) show mean \pm SEM for $n=6$. ${ }^{*} P<0.05$. SA: salinomycin, 2a: carbamate, 2b: acetate, 2c: carbonate and 3: C1-methyl ester. (JPG $737 \mathrm{~kb}$ )

\section{Abbreviations}

ALDH: aldehyde dehydrogenase; CSCs: cancer stem cells:

DEAB: diethylaminobenzaldehyde; DMSO: dimethyl sulfoxide; EMT: epithelial to mesenchymal transition; MET: mesenchymal to epithelial transition;

PBS: phosphate-buffered saline; SA: salinomycin.

\section{Competing interests}

The authors declare that they have no competing interests.

\section{Authors' contributions}

XH carried out Western blot, flow cytometric analysis of cell surface markers and $\mathrm{ALDH}^{+}$cells, colony formation assay, immunofluorescence microscopy and performed the statistical analysis. SO carried out the flow cytometric analysis of cell cycle phase distribution. BB synthesized the compounds. SK carried out the wound-healing assay and Boyden chamber cell migration assay. SO, DS, BB, CH, $\mathrm{LP}$ and $\mathrm{XH}$ conceived of the study, its design and coordination and drafted the manuscript. All authors read and approved the final manuscript.

\section{Acknowledgements}

This work was supported by The Percy Falk Foundation, the Mrs Berta Kamprad Foundation, the Crafoord Foundation, the Swedish Research Council (VR), the Swedish Cancer Society, the Royal Academy of Sciences, and the Royal Physiographical Society in Lund. We thank Ewa Dahlberg for seeding cells and preparing medium.

\section{Author details}

'Department of Biology, Lund University, Lund, Sweden. ²Department of Chemistry, Center for Analysis and Synthesis, Lund University, Lund, Sweden. ${ }^{3}$ Department of Experimental Medical Science, Lund University, Lund, Sweden. ${ }^{4}$ Division of Oncology and Pathology, Department of Clinical 
Sciences Lund, Lund University Cancer Center/Medicon Village, Lund,

Sweden

Received: 25 June 2015 Accepted: 8 February 2016

Published online: 23 February 2016

\section{References}

1. Brewster AM, Hortobagyi GN, Broglio KR, Kau S-W, Santa-Maria CA, Arun B, Buzdar AU, Booser DJ, Valero V, Bondy M, Esteva FJ. Residual risk of breast cancer recurrence 5 years after adjuvant therapy. J Natl Cancer Inst. 2008; 100:1179-83.

2. Lobo NA, Shimono Y, Qian D, Clarke MF. The biology of cancer stem cells. Annu Rev Cell Dev Biol. 2007;23:675-99.

3. Abubaker K, Latifi A, Luwor R, Nazaretian S, Zhu H, Quinn MA, Thompson EW, Findlay JK, Ahmed N. Short-term single treatment of chemotherapy results in the enrichment of ovarian cancer stem cell-like cells leading to an increased tumor burden. Mol Cancer. 2013;12:24.

4. Craveiro V, Yang-Hartwich Y, Holmberg JC, Sumi NJ, Pizzonia J, Griffin B, Gill SK, Silasi D-A, Azodi M, Rutherford T, Alvero AB, Mor G. Phenotypic modifications in ovarian cancer stem cells following Paclitaxel treatment. Cancer Med. 2013;2:751-62.

5. Eyler CE, Rich JN. Survival of the fittest: cancer stem cells in therapeutic resistance and angiogenesis. J Clin Oncol. 2008;26:2839-45.

6. Morrison R, Schleicher SM, Sun Y, Niermann KJ, Kim S, Spratt DE, Chung CH, Lu. Targeting the mechanisms of resistance to chemotherapy and radiotherapy with the cancer stem cell hypothesis. J Oncol. 2011;2011:941876.

7. Gupta PB, Onder TT, Jiang G, Tao K, Kuperwasser C, Weinberg RA, Lander ES. Identification of Selective Inhibitors of Cancer Stem Cells by High-Throughput Screening. Cell. 2009;138:1-15.

8. Bardsley MR, Horváth VJ, Asuzu DT, Lorincz A, Redelman D, Hayashi Y, Popko LN, Young DL, Lomberk GA, Urrutia RA, Farrugia G, Rubin BP, Ordog T. Kitlow stem cells cause resistance to Kit/platelet-derived growth factor alpha inhibitors in murine gastrointestinal stromal tumors. Gastroenterology. 2010;139:942-52.

9. Dong T-T, Zhou H-M, Wang L-L, Feng B, Lv B, Zheng M-H. Salinomycin selectively targets "CD133+" cell subpopulations and decreases malignant traits in colorectal cancer lines. Ann Surg Oncol. 2011;18:1797-804.

10. Larzabal L, El-Nikhely N, Redrado M, Seeger W, Savai R, Calvo A. Differential effects of drugs targeting cancer stem cell (CSC) and non-CSC populations on lung primary tumors and metastasis. PLoS One. 2013;8:e79798.

11. Lieke T, Ramackers W, Bergmann S, Klempnauer J, Winkler M, Klose J. Impact of Salinomycin on human cholangiocarcinoma: induction of apoptosis and impairment of tumor cell proliferation in vitro. BMC Cancer. 2012;12:466.

12. Wang F, He L, Dai W-Q, Xu Y-P, Wu D, Lin C-L, Wu S-M, Cheng P, Zhang Y, Shen M, Wang C-F, Lu J, Zhou Y-Q, Xu X-F, Xu L, Guo C-Y. Salinomycin inhibits proliferation and induces apoptosis of human hepatocellular carcinoma cells in vitro and in vivo. PLoS One. 2012;7:e50638.

13. Jangamreddy JR, Ghavami S, Grabarek J, Kratz G, Wiechec E, Fredriksson B-A, Rao Pariti RK, Cieślar-Pobuda A, Panigrahi S, Łos MJ. Salinomycin induces activation of autophagy, mitophagy and affects mitochondrial polarity: differences between primary and cancer cells. Biochim Biophys Acta. 1833; 2013:2057-69

14. Kopp F, Hermawan A, Oak PS, Herrmann A, Wagner E, Roidl A. Salinomycin treatment reduces metastatic tumor burden by hampering cancer cell migration. Mol Cancer. 2014;13:16.

15. Schenk M, Aykut B, Teske C, Giese NA, Weitz J, Welsch T. Salinomycin inhibits growth of pancreatic cancer and cancer cell migration by disruption of actin stress fiber integrity. Cancer Lett. 2015;358:161-9.

16. Lu D, Choi MY, Yu J, Castro JE, Kipps TJ, Carson DA. Salinomycin inhibits Wnt signaling and selectively induces apoptosis in chronic lymphocytic leukemia cells. Proc Natl Acad Sci U S A. 2011;108:13253-7.

17. Mao J, Fan S, Ma W, Fan P, Wang B, Zhang J, Yu X, Wang L, Song B, Li L. Roles of Wnt/ $\beta$-catenin signaling in the gastric cancer stem cells proliferation and salinomycin treatment. Cell Death Dis. 2014;5:e1039.

18. Lu W, Li Y. Salinomycin suppresses LRP6 expression and inhibits both Wnt/ $\beta$-catenin and mTORC1 signaling in breast and prostate cancer cells. J Cell Biochem. 2014;115(10):1799-807.

19. Lu Y, Ma W, Mao J, Yu X, Hou Z, Fan S, Song B, Wang H, Li J, Kang L, Liu P, Liu Q, Li L. Salinomycin exerts anticancer effects on human breast carcinoma MCF-7 cancer stem cells via modulation of Hedgehog signaling. Chem Biol Interact. 2015;228:100-7.
20. Fuchs D, Daniel V, Sadeghi M, Opelz G, Naujokat C. Salinomycin overcomes $A B C$ transporter-mediated multidrug and apoptosis resistance in human leukemia stem cell-like KG-1a cells. Biochem Biophys Res Commun. 2010; 394:1098-104.

21. Riccioni R, Dupuis ML, Bernabei M, Petrucci E, Pasquini L, Mariani G, Cianfriglia M, Testa $U$. The cancer stem cell selective inhibitor salinomycin is a p-glycoprotein inhibitor. Blood Cells Mol Dis. 2010;45:86-92.

22. Ketola K, Hilvo M, Hyötyläinen T, Vuoristo A, Ruskeepää A-L, Orešič M, Kallioniemi O, Ijin K. Salinomycin inhibits prostate cancer growth and migration via induction of oxidative stress. Br J Cancer. 2012;106:99-106.

23. Verdoodt B, Vogt M, Schmitz I, Liffers ST, Tannapfel A, Mirmohammadsadegh A. Salinomycin Induces Autophagy in Colon and Breast Cancer Cells with Concomitant Generation of Reactive Oxygen Species. PLoS One. 2012;7:e44132.

24. Wang D, Upadhyaya B, Liu Y, Knudsen D, Dey M. Phenethyl isothiocyanate upregulates death receptors 4 and 5 and inhibits proliferation in human cancer stem-like cells. BMC Cancer. 2014;14:591.

25. Kim KY, Yu SN, Lee SY, Chun SS, Choi YL, Park YM, Song CS, Chatterjee B, Ahn SC. Salinomycin-induced apoptosis of human prostate cancer cells due to accumulated reactive oxygen species and mitochondrial membrane depolarization. Biochem Biophys Res Commun. 2011;413:80-6.

26. Kim J-H, Chae M, Kim WK, Kim Y-J, Kang HS, Kim HS, Yoon S. Salinomycin sensitizes cancer cells to the effects of doxorubicin and etoposide treatment by increasing DNA damage and reducing p21 protein. Br J Pharmacol. 2011; 162:773-84.

27. Mitani M, Yamanishi T, Miyazaki Y, Otake N. Salinomycin effects on mitochondrial ion translocation and respiration. Antimicrob Agents Chemother. 1976;9:655-60.

28. Naujokata C, Lauferc S. Targeting cancer stem cells with defined compounds and drugs. J Cancer Res. 2013;2:36-67.

29. Naujokat C, Steinhart R. Salinomycin as a drug for targeting human cancer stem cells. J Biomed Biotechnol. 2012;2012:950658.

30. Borgström B, Huang X, Pošta M, Hegardt C, Oredsson S, Strand D. Synthetic modification of salinomycin: selective O-acylation and biological evaluation. Chem Commun (Camb). 2013;49:9944-6.

31. Miyazaki Y, Kinashi H, Otake N, Mitani M, Yamanishi T. Chemical Modification and Structure-Activity Correlation of Salinomycin. Agric Biol Chem. 1976;40: 1633-40.

32. Huczyński A, Janczak J, Antoszczak M, Wietrzyk J, Maj E, Brzezinski B. Antiproliferative activity of salinomycin and its derivatives. Bioorg Med Chem Lett. 2012;22:7146-50.

33. Antoszczak M, Popiel K, Stefańska J, Wietrzyk J, Maj E, Janczak J, Michalska G, Brzezinski B, Huczyński A. Synthesis, cytotoxicity and antibacterial activity of new esters of polyether antibiotic - salinomycin. Eur J Med Chem. 2014;76: 435-44.

34. Huczyński A, Antoszczak M, Kleczewska N, Lewandowska M, Maj E, Stefańska J, Wietrzyk J, Janczak J, Celewicz L. Synthesis and biological activity of salinomycin conjugates with floxuridine. Eur J Med Chem. 2015;93:33-41.

35. Huang X, Borgström B, Månsson L, Persson L, Oredsson S, Hegardt C, Strand D. Semisynthesis of SY-1 for investigation of breast cancer stem cell selectivity of C-Ring-modified salinomycin analogues. ACS Chem Biol. 2014; 9:1587-94.

36. Tanner M, Kapanen Al, Junttila T, Raheem O, Grenman S, Elo J, Elenius K, Isola J. Characterization of a novel cell line established from a patient with Herceptin-resistant breast cancer. Mol Cancer Ther. 2004;3:1585-92.

37. Jönsson G, Staaf J, Olsson E, Heidenblad M, Vallon-Christersson J, Osoegawa K de Jong $P$, Oredsson S, Ringnér M, Höglund M BA. High-resolution genomic profiles of breast cancer cell lines assessed by tiling BAC array comparative genomic hybridization. Genes Chromosomes Cancer. 2007;46:543-58.

38. Olsson $E_{1}$ Honeth $G$, Bendahl P-O, Saal LH, Gruvberger-Saal S, Ringnér M, Vallon-Christersson J, Jönsson G, Holm K, Lövgren K, Fernö M, Grabau D, Borg $\AA$, Hegardt C. CD44 isoforms are heterogeneously expressed in breast cancer and correlate with tumor subtypes and cancer stem cell markers. BMC Cancer. 2011;11:418.

39. Cufí S, Vazquez-Martin A, Oliveras-Ferraros C, Martin-Castillo B, Vellon L, Menendez I a. Autophagy positively regulates the CD44 + CD24 -/low breast cancer stem-like phenotype. Cell Cycle. 2011;10:3871-85.

40. Cufi S, Corominas-Faja B, Vazquez-Martin A, Oliveras-Ferraros C, Dorca J, Bosch-Barrera J, Martin-Castillo B, Menendez JA. Metformin-induced preferential killing of breast cancer initiating CD44 + CD24-/low cells is sufficient to overcome primary resistance to trastuzumab in HER2+ human breast cancer xenografts. Oncotarget. 2012;3:395-8. 
41. Silva TM, Fiuza SM, Marques MPM, Persson L, Oredsson S. Increased breast cancer cell toxicity by palladination of the polyamine analogue N (1), N (11)-bis(ethyl)norspermine. Amino Acids. 2014;46:339-52.

42. Cirenajwis H, Smiljanic S, Honeth G, Hegardt C, Marton LJ, Oredsson SM. Reduction of the putative CD44 + CD24- breast cancer stem cell population by targeting the polyamine metabolic pathway with PG11047. Anticancer Drugs. 2010;21:897-906.

43. Alm K, Berntsson P, Oredsson SM. Topoisomerase II is nonfunctional in polyamine-depleted cells. J Cell Biochem. 1999;75:46-55.

44. Al-Hajj M, Wicha MS, Benito-Hernandez A, Morrison SJ, Clarke MF. Prospective identification of tumorigenic breast cancer cells. Proc Natl Acad Sci U S A. 2003;100:3983-8

45. Ginestier $C_{1}$ Hur MH, Charafe-Jauffret E, Monville F, Dutcher J, Brown M, Jacquemier J, Viens P, Kleer CG, Liu S, Schott A, Hayes D, Birnbaum D, Wicha MS, Dontu G. ALDH1 is a marker of normal and malignant human mammary stem cells and a predictor of poor clinical outcome. Cell Stem Cell. 2007;1:555-67.

46. Dontu G, Abdallah WM, Foley JM, Jackson KW, Clarke MF, Kawamura MJ, Wicha MS. In vitro propagation and transcriptional profiling of human mammary stem / progenitor cells. Genes Dev. 2003;17:1253-70.

47. Hollier BG, Evans K, Mani SA. The epithelial-to-mesenchymal transition and cancer stem cells: a coalition against cancer therapies. J Mammary Gland Biol Neoplasia. 2009;14:29-43.

48. Mani S a, Guo W, Liao M-J, Eaton EN, Ayyanan A, Zhou AY, Brooks M, Reinhard F, Zhang CC, Shipitsin M, Campbell LL, Polyak K, Brisken C, Yang J, Weinberg $\mathrm{R}$ a. The epithelial-mesenchymal transition generates cells with properties of stem cells. Cell. 2008;133:704-15.

49. Santisteban M, Reiman JM, Asiedu MK, Behrens MD, Nassar A, Kalli KR, Haluska P, Ingle JN, Hartmann LC, Manjili MH, Radisky DC, Ferrone S, Knutson KL. Immune-induced epithelial to mesenchymal transition in vivo generates breast cancer stem cells. Cancer Res. 2009;69:2887-95.

50. Heuberger J, Birchmeier W. Interplay of cadherin-mediated cell adhesion and canonical Wnt signaling. Cold Spring Harb Perspect Biol. 2010;2:a002915.

51. Tian X, Liu Z, Niu B, Zhang J, Tan TK, Lee SR, Zhao Y, Harris DCH, Zheng G. E-cadherin/ $\beta$-catenin complex and the epithelial barrier. J Biomed Biotechnol. 2011;2011:567305.

52. Yoon MJ, Kang YJ, Kim IY, Kim EH, Lee JA, Lim JH, Kwon TK, Choi KS. Monensin, a polyether ionophore antibiotic, overcomes TRAlL resistance in glioma cells via endoplasmic reticulum stress, DR5 upregulation and c-FLIP downregulation. Carcinogenesis. 2013;34:1918-28.

53. Davis FM, Stewart TA, Thompson EW, Monteith GR. Targeting EMT in cancer: opportunities for pharmacological intervention. Trends Pharmacol Sci. 2014; 35:479-88.

54. Scherzed A, Hackenberg S, Froelich K, Rak K, Technau A, Radeloff A, Nöth U, Koehler C, Hagen R, Kleinsasser N. Effects of salinomycin on human bone marrow-derived mesenchymal stem cells in vitro. Toxicol Lett. 2013;218: 207-14

55. Kusunoki S, Kato K, Tabu K, Inagaki T, Okabe H, Kaneda H, Suga S, Terao Y, Taga T, Takeda S. The inhibitory effect of salinomycin on the proliferation, migration and invasion of human endometrial cancer stem-like cells. Gynecol Oncol. 2013;129:598-605.

\section{Submit your next manuscript to BioMed Central and we will help you at every step:}

- We accept pre-submission inquiries

- Our selector tool helps you to find the most relevant journal

- We provide round the clock customer support

- Convenient online submission

- Thorough peer review

- Inclusion in PubMed and all major indexing services

- Maximum visibility for your research

Submit your manuscript at www.biomedcentral.com/submit

) Biomed Central 